University of Nebraska - Lincoln

DigitalCommons@University of Nebraska - Lincoln

Civil Engineering Faculty Publications

Civil Engineering

2006

\title{
Dissolution Kinetics of High Explosives Particles in a Saturated Sandy Soil
}

\author{
Matthew C. Morley \\ University of Nebraska - Lincoln \\ Hiroshi Yamamoto \\ University of Texas at Austin, 1 University Station C1700, Austin, TX 78712-0273, United States \\ Gerald E. Speitel, Jr. \\ University of Texas at Austin, 1 University Station C1700, Austin, TX 78712-0273, United States \\ Jay Clausen \\ U.S. Army Corps of Engineers, Engineer Research and Development Center, Cold Regions Research and \\ Engineering Laboratory, Hanover, NH 03755-1290, United States
}

Follow this and additional works at: https://digitalcommons.unl.edu/civilengfacpub

Part of the Civil Engineering Commons

Morley, Matthew C.; Yamamoto, Hiroshi; Speitel, Jr., Gerald E.; and Clausen, Jay, "Dissolution Kinetics of High Explosives Particles in a Saturated Sandy Soil" (2006). Civil Engineering Faculty Publications. 24. https://digitalcommons.unl.edu/civilengfacpub/24

This Article is brought to you for free and open access by the Civil Engineering at DigitalCommons@University of Nebraska - Lincoln. It has been accepted for inclusion in Civil Engineering Faculty Publications by an authorized administrator of DigitalCommons@University of Nebraska - Lincoln. 


\title{
Dissolution kinetics of high explosives particles in a saturated sandy soil
}

\author{
Matthew C. Morley ${ }^{\mathrm{a}, *}$, Hiroshi Yamamoto ${ }^{\mathrm{b}, 1}$, \\ Gerald E. Speitel Jr. ${ }^{\mathrm{b}}$, Jay Clausen ${ }^{\mathrm{c}}$ \\ a University of Nebraska Lincoln, Department of Civil Engineering, W348 Nebraska Hall, Lincoln, \\ NE 68588-0531, United States \\ b Department of Civil, Architectural and Environmental Engineering, University of Texas at Austin, \\ 1 University Station C1700, Austin, TX 78712-0273, United States \\ ${ }^{\mathrm{c}}$ U.S. Army Corps of Engineers, Engineer Research and Development Center, \\ Cold Regions Research and Engineering Laboratory, Hanover, NH 03755-1290, United States
}

Received 16 November 2004; received in revised form 16 January 2006; accepted 19 January 2006 Available online 10 March 2006

\begin{abstract}
Solid phase high explosive (HE) residues from munitions detonation may be a persistent source of soil and groundwater contamination at military training ranges. Saturated soil column tests were conducted to observe the dissolution behavior of individual components (RDX, HMX, and TNT) from two HE formulations (Comp B and C4). HE particles dissolved readily, with higher velocities yielding higher dissolution rates, higher mass transfer coefficients, and lower effluent concentrations. Effluent concentrations were below solubility limits for all components at superficial velocities of $10-50 \mathrm{~cm} \mathrm{day}^{-1}$. Under continuous flow at $50 \mathrm{~cm} \mathrm{day}^{-1}$, RDX dissolution rates from Comp B and C4 were 34.6 and $97.6 \mu \mathrm{g} \mathrm{h}^{-1} \mathrm{~cm}^{-2}$ (based on initial RDX surface area), respectively, significantly lower than previously reported dissolution rates. Cycling between flow and no-flow conditions had a small effect on the dissolution rates and effluent concentrations; however, TNT dissolution from Comp B was enhanced under intermittent-flow conditions. A model that includes advection, dispersion, and film transfer resistance was developed to estimate the steady-state effluent concentrations.
\end{abstract}

(C) 2006 Elsevier B.V. All rights reserved.

Keywords: Explosives; Dissolution; Kinetics; Composition B; C4; Contaminant flux; Mass transfer

\footnotetext{
* Corresponding author. Tel.: +1 402472 2057; fax: +1 4024728934.

E-mail addresses: mmorley2@yahoo.com (M.C. Morley), hiroshi@ias.tokushima-u.ac.jp (H. Yamamoto).

${ }^{1}$ Present address: Department of Mathematical and Natural Sciences, Faculty of Integrated Arts and Sciences, The University of Tokushima, 1-1 Minamijosanjima-cho, Tokushima, 770-8502, Japan.
}

0169-7722/\$ - see front matter (C) 2006 Elsevier B.V. All rights reserved. doi:10.1016/j.jconhyd.2006.01.003 


\section{Introduction}

Contamination of soil and groundwater with high explosive (HE) compounds has been observed at many military training ranges (Jenkins et al., 2001; Pennington et al., 2002; Clausen et al., 2004). The primary source of HE contamination at these sites is residues from detonation of military munitions including projectiles (e.g., mortar and artillery rounds), grenades, land mines, aerial bombs, and missiles, as well as ordnance demolition charges. At one military installation in the eastern US, surface and underlying soils have significant HE contamination as a result of more than 50 years of live-fire training. The main soil contaminants are the high explosives hexahydro-1,3,5-trinitro-1,3,5-triazine (RDX) and 2,4,6-trinitrotoluene (TNT), although other contaminants such as 2,4-dinitrotolune (2,4-DNT), nitroglycerine (NG), and octahydro-1,3,5,7-tetranitro-1,3,5,7-tetrazocine (HMX) have also been detected. RDX has been detected in soil at concentrations up to $16,000 \mathrm{mg} \mathrm{kg}^{-1}$, although $\mathrm{HE}$ levels have generally been $<1 \mathrm{mg} \mathrm{kg}^{-1}$. Most HE contamination exists in near-surface soils and in the vicinity of firing range targets (Clausen et al., 2004). A primary concern is that soil contaminants may eventually migrate to groundwater and contaminate drinking water supplies of nearby communities. RDX is particularly worrisome because it is highly mobile in the subsurface and toxic to humans.

Military munitions typically utilize HE formulations such as Composition C4 (C4), composed of RDX and plasticizers, and Composition B (Comp B), a mixture of RDX and TNT, as their main charges (Jenkins et al., 2002). These formulations and many other organic chemicals are also used in munitions for primers, fuses, and ignition and propellant charges (Jenkins et al., 2002). The yield of a detonation is the fraction of HE that detonates. Types of detonations include dud (little or no explosion, resulting in unexploded ordnance), low order (a significant amount of HE does not detonate), or the desired high order, in which nearly $100 \%$ of the HE is detonated (Taylor et al., 2004). Depending on the munition type, up to $4.4 \%$ and $0.22 \%$ of all detonations may be duds and low-order detonations, respectively (Jenkins et al., 2001).

Any type of detonation deposits HE residues on the ground surface. Radtke et al. (2002) estimated that there were 19,900 TNT particles larger than $3 \mathrm{~mm}$ per cubic yard of surface soil from an explosives testing range, for a total mass of $1.7 \mathrm{~kg}$ of TNT. Taylor et al. (2004) measured residues from detonations of $155-\mathrm{mm}$ howitzer rounds containing $6.76 \mathrm{~kg}$ of TNT. For low- and high-order detonations, an estimated $40-44 \%$ and $1-3 \%$ of the TNT charge was deposited on the ground surface, respectively, with many large TNT pieces observed for both. Jenkins et al. (2002) found $4430 \mu \mathrm{g} \mathrm{RDX} \mathrm{m}{ }^{-2}$ and $40 \mu \mathrm{g}$ TNT m ${ }^{-2}$ deposited on a clean snow surface at after a high-order detonation of an 81-mm mortar round. Thus, even if only a small fraction of the total HE mass within a munition is not consumed during a detonation, repeated blasts at training ranges and impact areas will result in significant $\mathrm{HE}$ accumulation in surface soils, establishing a source of potentially leachable contaminants.

Although dissolution of HE particles and residues is the first and possibly rate-limiting step in the migration of HEs from firing ranges (Brannon et al., 1999), little is known about the rates or mechanisms that govern in-situ dissolution of HE residues prior to subsurface transport and transformation. Several previous studies (Lynch et al., 2002a,b; Pennington et al., 2002; Phelan et al., 2002) reported dissolution kinetics of HE compounds and formulations in batch reactors and found that dissolution rates generally increased with temperature and particle surface area. In single component dissolution tests with military-grade TNT, RDX, and HMX, TNT had the fastest dissolution rate (Lynch et al., 2002a). Dissolution rates of component HEs from Comp B were similar to the dissolution rates of pure HEs (Lynch et al., 2002b; Pennington et al., 2002), 
but TNT reached its maximum concentration faster than RDX during dissolution of Comp B particles under all conditions (Phelan et al., 2002).

Although these studies provide insight into HE dissolution rates, dissolution rates of $\mathrm{HE}$ particles under conditions that may be relevant to contaminated soils at training ranges or impact areas were not studied. This research was undertaken to determine HE particle dissolution kinetics during infiltration through saturated soil at various water velocities and conditions of continuous and intermittent flow. Two HE formulations, C4 and Comp B, were studied to determine RDX, HMX, and TNT dissolution rates, and a dissolution model that included advection, dispersion, and film transfer resistance was developed to estimate steady state effluent concentrations. These results can be combined with detailed fate and transport modeling to estimate exposure concentrations in on- and off-post groundwater in the vicinity of a site.

\section{Materials and methods}

\subsection{Soil samples}

All soil used in these experiments was uncontaminated and was a composite of samples from approximately $100 \mathrm{ft}$ below ground surface from two borings near an Impact Area at the eastern US military installation. The soil consisted of approximately $97.3 \%$ sand $(>0.075 \mathrm{~mm}), 2.7 \%$ silt and clay, and $0.04 \%$ organic matter. Based on the grain size distribution, the approximate geometric mean particle diameter was $0.35 \mathrm{~mm}$. The soil had the following characteristics: bulk density $1.61 \mathrm{~g} \cdot \mathrm{cm}^{-3}$; particle density $2.63 \mathrm{~g} \cdot \mathrm{cm}^{-3} ; \mathrm{pH} 6.12$; cation exchange capacity $1.17 \mathrm{meq} \cdot(100 \mathrm{~g})^{-1}$; and total iron $331 \mathrm{mg} \cdot \mathrm{kg}^{-1}$. Further details of the site-specific soil properties are presented by Yamamoto et al. (2004).

\subsection{High explosives}

Two HE formulations were used in these experiments. C4 is a plastic explosive that is used in bursting charges and shaped demolition charges (Fedoroff and Sheffield, 1966). When manufactured, $\mathrm{C} 4$ has a density of $1.58-1.60 \mathrm{~g} \mathrm{~cm}^{-3}$ and consists of $91 \%$ military-grade RDX and $9 \%$ plasticizers by mass (Fedoroff and Sheffield, 1966). Typical military-grade RDX has about $10 \%$ HMX by mass (Phelan et al., 2002); thus, the C4 consisted of approximately $81.9 \%$ RDX, $9.1 \% \mathrm{HMX}$, and $9 \%$ plasticizers by mass. C4 particles $(\sim 1 \mathrm{~cm}$ diameter $)$ were collected from the demolition area ground surface of the eastern US military installation. Prior to our experiments, the $\mathrm{C} 4$ particles were submerged in water, crushed to reduce the particle diameter to $\sim 2 \mathrm{~mm}$, and air dried. Although the size reduction of the $\mathrm{C} 4$ particles produced fresh, unweathered surfaces that may have biased dissolution rates, HE particles with diameters $<1 \mathrm{~cm}$ are expected to be more widespread at contaminated sites (Taylor et al., 2004). Assuming the C4 particles were 2-mm spheres with a density of $1.59 \mathrm{~g} \mathrm{~cm}^{-3}$, the specific surface area was about $18.8 \mathrm{~cm}^{2} \mathrm{~g}^{-1}$.

Comp B includes several different formulations that consist of about $60 \%$ RDX and $40 \%$ TNT by weight (Fedoroff and Sheffield, 1966). The resulting mixture is castable, has a density of about $1.68-1.71 \mathrm{~g} \mathrm{~cm}^{-3}$, and is used in numerous types of military ordnance, including artillery shells, land mines, and rockets (Fedoroff and Sheffield, 1966). Comp B particles were provided by James Phelan (Sandia National Laboratories, Albuquerque, NM), who originally obtained them from the McAlester Army Depot (McAlester, OK). Comp B particles had particle diameters of $0.5-0.6 \mathrm{~mm}$, a spherical specific surface area of about $66 \mathrm{~cm}^{2} \mathrm{~g}^{-1}$, and consisted of 54\% RDX, 6\% HMX, and 40\% TNT (Phelan et al., 2003). 


\subsection{Dissolution experiments}

Four column dissolution experiments were conducted at room temperature $\left(\sim 22{ }^{\circ} \mathrm{C}\right)$. One continuous flow and one intermittent flow (cycling between flow and no flow conditions) experiment were conducted for each HE formulation. Each column experiment was prepared by mixing $0.5 \mathrm{~g}$ of Comp B or C4 particles with $80 \mathrm{~g}$ of clean soil. For the Comp B experiments, the initial masses of RDX, HMX, and TNT were approximately $0.27,0.03$, and $0.2 \mathrm{~g}$, respectively. Initial masses of approximately $0.41 \mathrm{~g}$ RDX and $0.046 \mathrm{~g} \mathrm{HMX}$ were placed in the columns for the $\mathrm{C} 4$ experiments. The soil-HE mixtures were packed into $5-\mathrm{cm}$ diameter glass columns to provide a source zone depth of approximately $2.5 \mathrm{~cm}$. Additional clean soil was placed both above $(160 \mathrm{~g})$ and below $(80 \mathrm{~g})$ the soil-HE mixture. The porosity of the packed soil columns was 0.4 .

Uncontaminated rainwater collected at the military installation was pumped into each column using a peristaltic pump. A water depth of approximately $5 \mathrm{~cm}$ was maintained over the top of the soil, thereby maintaining saturated conditions in each column. The effluent was sampled with a fraction collector, and RDX, HMX, and TNT concentrations were measured via high performance liquid chromatography (HPLC) according to USEPA Method 8330 (USEPA, 1994).

The duration of each continuous-flow column test was $120 \mathrm{~h}$. For the first $72 \mathrm{~h}$, the superficial velocity was $10 \mathrm{~cm} \mathrm{day}^{-1}$ (flow rate of $\sim 0.14 \mathrm{~mL} \mathrm{~min}^{-1}$ ). Preliminary analytical results suggested that steady-state effluent RDX and TNT concentrations were achieved within $12 \mathrm{~h}$ and $48 \mathrm{~h}$, respectively; thus, the flow rate was increased to $0.42 \mathrm{~mL} \mathrm{~min}{ }^{-1}$ (superficial velocity of $30 \mathrm{~cm} \mathrm{day}^{-1}$ ) at $72 \mathrm{~h}$. The flow rate was increased again at $96 \mathrm{~h}$ to a superficial velocity of $50 \mathrm{~cm}$ day $^{-1}\left(\sim 0.7 \mathrm{~mL} \mathrm{~min}^{-1}\right)$.

Intermittent flow column tests simulated alternating periods of saturated flow and stagnation. During each flow period, the superficial velocity was constant at $10 \mathrm{~cm} \mathrm{day}^{-1}$. At the end of each 24-h flow period, the flow was halted by stopping the pump, but the soil was not drained. No-flow periods of $1,2,4,8$, and $24 \mathrm{~h}$ were applied, each of which was followed by $24 \mathrm{~h}$ of flow. During the no flow periods, each column remained saturated with water contacting the HE particles.

\section{Dissolution modeling}

For each column operating condition, both non-steady-state and steady-state effluent concentrations were observed. Dissolution kinetics was estimated by fitting a mass transport model to the period of steady-state performance. Two similar approaches were used for modeling dissolution of HE particles in the soil columns; one included dispersion in the bulk liquid phase, while the other did not. The dissolution model was developed with the following assumptions and limitations:

1. the specific surface area and mass of source particles do not vary over time;

2. the overall rate of dissolution is limited by mass transport kinetics across the liquid film surrounding the HE particles;

3. the solvation step is much faster than the mass transfer step; thus, each component in an HE mixture dissolves instantaneously into the liquid phase at the water-HE interface, yielding liquid phase $\mathrm{HE}$ concentrations at the particle-liquid interface equal to the component solubility $\left(C_{\mathrm{s}}\right)$; 
4. contaminant interactions with soil particles (i.e., sorption) are negligible; and

5. reactions (i.e., biodegradation or surface-mediated degradation) are negligible.

In the column experiments, the HE concentration in the source zone can be calculated as

$$
X_{\mathrm{HE}}=\frac{M_{\mathrm{HE}}}{M_{\mathrm{s}}+M_{\mathrm{HE}}}
$$

where $X_{\mathrm{HE}}$ is the HE mass fraction $\left(\mathrm{g} \mathrm{g}^{-1}\right) ; M_{\mathrm{HE}}$ is the mass $(\mathrm{g})$ of HE in the source zone; and $M_{\mathrm{S}}$ is the soil mass $(\mathrm{g})$ in the HE source zone. For modeling, the HE particles were assumed to be uniformly distributed throughout the column. The resulting expression for mass transfer from the HE particles to liquid phase is:

$$
\text { Mass Transfer }\left(\operatorname{mg} L^{-1} d^{-1}\right)=k_{\mathrm{f}} a \phi\left(C_{\mathrm{s}}-C\right) X_{\mathrm{HE}} \rho_{\mathrm{b}}
$$

where $k_{\mathrm{f}}$ is the liquid-film mass transfer coefficient $\left(\mathrm{cm} \mathrm{day}^{-1}\right), a$ is the specific surface area of the HE particles $\left(\mathrm{cm}^{2} \mathrm{~g}^{-1}\right), \phi$ is the mass fraction of a specific compound in the HE formulation, $C$ is the HE concentration in the bulk liquid $\left(\mathrm{mg} \mathrm{L}^{-1}\right)$, and $\rho_{\mathrm{b}}$ is the packing density $\left(\mathrm{g} \mathrm{cm}^{-3}\right)$ in the soil column. We have assumed that each component's fraction of the total specific surface area is equivalent to its mass fraction $(\phi)$ in the HE formulation.

The resulting steady-state models with and without dispersion, respectively, are:

$$
\begin{aligned}
& v_{\mathrm{s}} \frac{\mathrm{d} C}{\mathrm{~d} z}=D_{\mathrm{h}} \frac{\mathrm{d}^{2} C}{\mathrm{~d} z^{2}}+K\left(C_{\mathrm{s}}-C\right) \\
& v_{\mathrm{s}} \frac{\mathrm{d} C}{\mathrm{~d} z}=K\left(C_{\mathrm{s}}-C\right)
\end{aligned}
$$

where:

$$
K=\frac{a \phi X_{\mathrm{HE}} \rho_{\mathrm{b}} k_{\mathrm{f}}}{\varepsilon}
$$

and $z$ is axial position along the length of the column $(\mathrm{cm}), v_{\mathrm{S}}$ is the interstitial velocity $\left(\mathrm{cm} \mathrm{day}^{-1}\right)$, is the soil porosity, and $D_{\mathrm{h}}$ is the hydrodynamic dispersion coefficient $\left(\mathrm{cm}^{2} \mathrm{day}^{-1}\right)$ in the flow direction.

Assuming the boundary conditions of $C=0$ at $z=0$ and $C=C_{\mathrm{s}}$ at $z=\infty$, the solution to Eq. (3) is:

$$
C=C_{\mathrm{s}}\left(1-e^{K z}\right)
$$

where:

$$
K^{\prime}=\frac{v_{\mathrm{s}}}{2 D_{\mathrm{h}}}\left[1-\sqrt{1+\frac{4 K D_{\mathrm{h}}}{v_{\mathrm{s}}^{2}}}\right]
$$

The solution to Eq. (4) for the boundary condition of $C=0$ at $z=0$ is:

$$
C=C_{\mathrm{s}}\left(1-e^{-K z / v_{\mathrm{s}}}\right)
$$

Fitting of Eq. (6) to the steady-state effluent concentration data was the primary means of estimating $k_{\mathrm{f}}$, while Eq. (8) was used to examine the effect of dispersion on the estimate of $k_{\mathrm{f}}$. To 
fit Eq. (6) and estimate $k_{\mathrm{f}}$, values had to be assigned to $D_{\mathrm{h}}$ and $C_{\mathrm{s}}$. Solubilities at $22{ }^{\circ} \mathrm{C}$ were estimated from literature correlations and are as follows: $46.6 \mathrm{mg} \mathrm{RDX} \mathrm{L}^{-1}$ (Monteil-Rivera et al., 2004); $3.95 \mathrm{mg} \mathrm{HMX} \mathrm{L}^{-1}$ (Monteil-Rivera et al., 2004); and $117 \mathrm{mg} \mathrm{TNT} \mathrm{L}^{-1}$ (average of values from Phelan et al., 2002; Lynch et al., 2002b).

Tracer tests were conducted in associated research (Yamamoto et al., 2004) to estimate $D_{\mathrm{h}}$ for one of the flow conditions used in this research $\left(D_{\mathrm{h}}=26.56 \mathrm{~cm}^{2}\right.$ day $^{-1}$ for $v_{\mathrm{s}}=29.09 \mathrm{~cm}$ day $^{-1}$; same aquifer material). $D_{\mathrm{h}}$ was estimated for the other two flow conditions using the correlation proposed by Freeze and Cherry (1979):

$$
D_{\mathrm{h}}=\alpha v_{\mathrm{s}}+D^{*}
$$

where $\alpha$ is the longitudinal dispersivity of the porous medium $(0.892-0.895 \mathrm{~cm})$ and $D^{*}$ is the pore diffusion coefficient $\left(\mathrm{cm}^{2}\right.$ day $\left.{ }^{-1}\right)$. $D^{*}$ for each solute was approximated as the product of the porosity $(=0.4)$ and the free liquid diffusivities $\left(D_{\mathrm{L}}\right)$ from Rosenblatt et al. (1991).

Model-fit values of $k_{\mathrm{f}}$ were compared to the correlation developed by Powers et al. (1994) for dissolution of naphthalene spheres emplaced in a packed bed of sand. As in our dissolution experiments, the naphthalene spheres were a small fraction of the particles in the source zone. Powers et al. (1994) correlated the Sherwood number with the Reynolds number $(R e)$ as:

$$
S h=36.8 R e^{0.654}=\frac{k_{\mathrm{f}} l_{\mathrm{c}}}{D_{\mathrm{L}}}
$$

with $R e$ calculated using the interstitial velocity:

$$
R e=\frac{v_{\mathrm{s}} \rho_{\mathrm{w}} l_{\mathrm{c}}}{\mu_{\mathrm{w}}}
$$

where $\rho_{\mathrm{w}}$ is the density of water $\left(\mathrm{kg} \mathrm{m}^{-3}\right), l_{\mathrm{c}}$ is the characteristic length $(\mathrm{m}), D_{\mathrm{L}}$ is the free liquid diffusivity of the solute $\left(\mathrm{cm}^{2}\right.$ day $\left.^{-1}\right)$, and $\mu_{\mathrm{w}}$ is the viscosity of water $\left(\mathrm{kg} \mathrm{m}^{-1}\right.$ day $\left.^{-1}\right)$. Powers et al. (1994) obtained the best results when $l_{\mathrm{c}}$ was equated to the median sand grain diameter, rather than the contaminant sphere diameter.

\section{Results and discussion}

\subsection{Continuous-flow experiment-Comp B}

During the continuous flow Comp B experiment, the steady state effluent concentrations generally decreased and were achieved more quickly as the superficial velocity was increased (Fig. 1), illustrating that HE dissolution under these flow conditions is limited by the kinetics of mass transfer. The RDX and HMX concentrations reached steady-state concentrations of approximately 28 and $2.3 \mathrm{mg} \mathrm{L}^{-1}$, respectively, in about $12 \mathrm{~h}$ at a superficial velocity of $10 \mathrm{~cm}$ day $^{-1}$ (Fig. 1), whereas the steady state TNT concentration $\left(\sim 22 \mathrm{mg} \mathrm{L}^{-1}\right)$ was not reached until about 48 hours. At a superficial velocity of $30 \mathrm{~cm} \mathrm{day}^{-1}$, TNT did not reach a steady state concentration, while RDX and HMX attained steady state concentrations of about $19 \mathrm{mg} \mathrm{L}^{-1}$ and $1.3 \mathrm{mg} \mathrm{L}^{-1}$, respectively. After increasing the superficial velocity to $50 \mathrm{~cm}$ day $^{-1}$, the effluent contaminant concentrations again decreased, reaching steady state values at about $99 \mathrm{~h}$ of about $15 \mathrm{mg} \mathrm{L}^{-1}$ for RDX and TNT and about $0.8 \mathrm{mg} \mathrm{L}^{-1}$ for HMX.

None of the three components of Comp B reached their solubility limits. The highest steadystate RDX, HMX, and TNT concentrations (which all occurred at $10 \mathrm{~cm}$ day $^{-1}$ ) were approximately $60 \%, 58 \%$ and $19 \%$ of the pure compound aqueous solubilities. The steady-state 


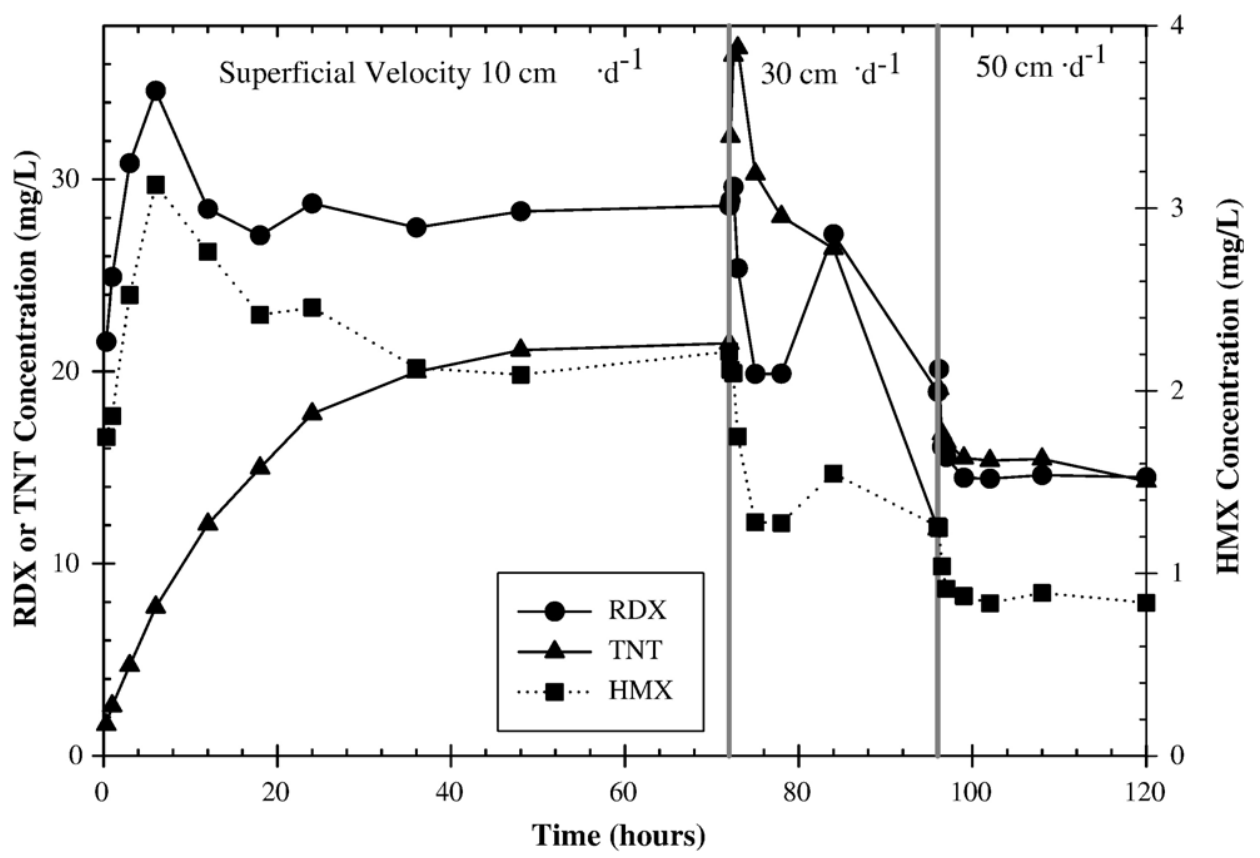

Fig. 1. Effluent RDX, HMX, and TNT concentrations during the Comp B continuous flow experiment.

RDX and TNT concentrations at $10 \mathrm{~cm}^{\text {day }}{ }^{-1}$ were also significantly lower than the concentrations that Phelan et al. (2002) obtained when dissolving the same material in wellmixed batch reactors with no soil. In their experiments, the maximum RDX and TNT concentrations were approximately 40 and $110 \mathrm{mg} \mathrm{L}^{-1}$, respectively (Phelan et al., 2002). The lower concentrations observed during our experiments were most likely due to mass transfer limitations imposed by flow conditions in the packed soil column, but interactions between dissolved contaminants and the soil particles, particularly for TNT (Yamamoto et al., 2004), may have reduced effluent concentrations.

\subsection{Intermittent-flow experiment-Comp B}

Over the first $24 \mathrm{~h}$ of the intermittent-flow Comp B experiment (Fig. 2), RDX and HMX effluent concentrations increased rapidly and were similar to those during the first $24 \mathrm{~h}$ of the continuous-flow Comp B experiment. The effluent TNT concentration increased rapidly to about $50 \mathrm{mg} \mathrm{L}^{-1}$ within $6 \mathrm{~h}$, which was significantly faster and higher than the $22 \mathrm{mg} \mathrm{L}^{-1}$ during the continuous-flow Comp B experiment at $10 \mathrm{~cm}_{\text {day }}{ }^{-1}$. This observation is puzzling because of the identical setup and operation of the intermittent and continuous-flow columns during the first $24 \mathrm{~h}$. However, the TNT concentration was still less than half the solubility of TNT $\left(117 \mathrm{mg} \mathrm{L}^{-1}\right)$ and the maximum TNT concentration $\left(110 \mathrm{mg} \mathrm{L}^{-1}\right)$ obtained by Phelan et al. (2002) using the same source material in well-mixed batch reactors.

In general, pseudo-steady state effluent concentrations for all components were highest during the first and final 24-h flow periods, while the lowest steady state concentrations occurred in the middle of the experiment (79-103 h). Because the column remained saturated while the flow was stopped, Comp B continued to dissolve into stagnant pore water during periods of no 


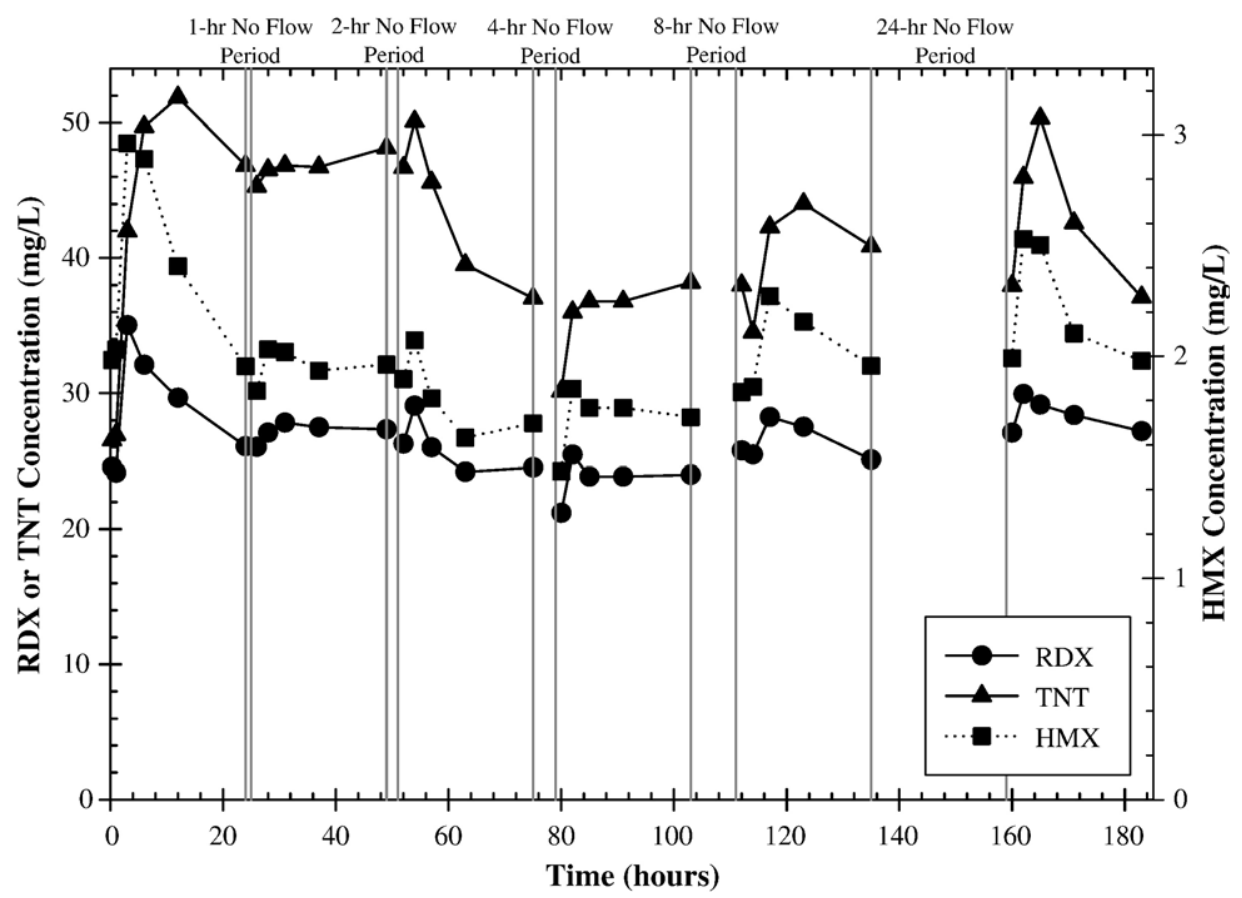

Fig. 2. Effluent RDX, HMX, and TNT concentrations during the intermittent flow Comp B experiment.

flow, resulting in some effluent concentration peaks during subsequent start-up. RDX and HMX approached steady state effluent concentrations during each flow period, although these concentrations varied throughout the experiment. The effluent TNT concentration decreased considerably between 50 and $72 \mathrm{~h}$ of operation, but remained much higher than the $22 \mathrm{mg} \mathrm{L}^{-1}$ observed during the continuous-flow experiment. This decrease may have been caused by the onset of chemical or biological degradation reactions, which significantly affect transport of TNT through this aquifer material (Yamamoto et al., 2004).

\subsection{Continuous-flow experiment-C4}

Steady state RDX and HMX concentrations produced by continuous-flow C4 dissolution decreased as the superficial velocity was increased and were well below solubility limits during the experiment (Fig. 3), as in the continuous flow Comp B experiment. RDX and HMX steady state effluent concentrations were comparable to those during the continuous-flow Comp B test, which was unexpected given the differences in exposed surface areas for each component in these HE formulations. The estimated exposed surface areas for RDX and HMX in C4 were only about $43 \%$ of those for Comp B due to differences in HE composition and estimated particle surface areas. Comp B used in this work was well characterized by Phelan et al. (2002), whereas the characterization of the $\mathrm{C} 4$ particles was less certain. The similarity of RDX and HMX concentrations from the $\mathrm{C} 4$ and Comp B experiments suggests that $\mathrm{C} 4$ dissolves more readily than Comp B, although this possibility is not certain based solely on these data, or that the actual specific surface area of the $\mathrm{C} 4$ particles was higher than our estimates. In a similar study, Phelan et al. (2003) found that the measured specific surface area of the Comp B particles was much 


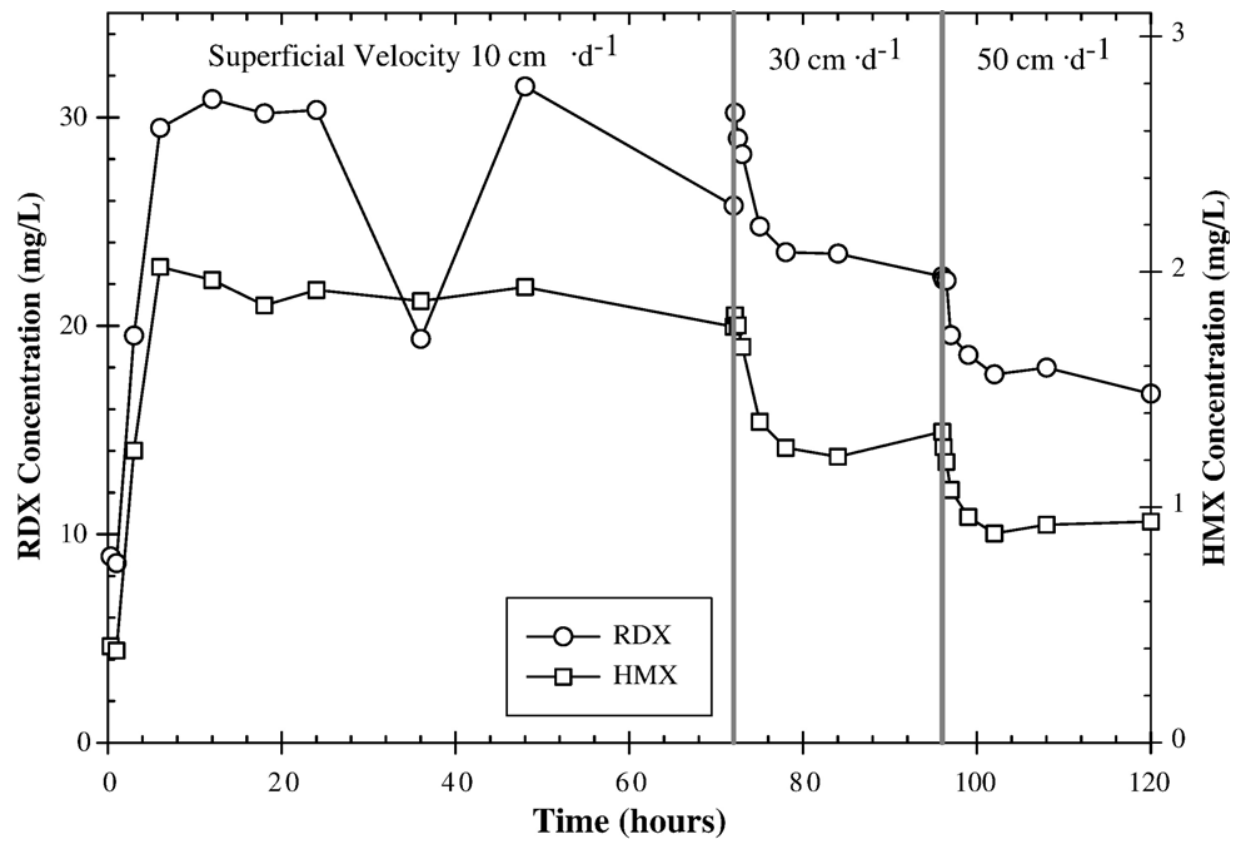

Fig. 3. Effluent RDX and HMX concentrations during the $\mathrm{C} 4$ continuous flow experiment.

greater than that calculated assuming uniform spherical particles due to smaller particles adhering to the larger HE particles.

\subsection{Intermittent-flow experiment-C4}

During the intermittent-flow C4 experiment (Fig. 4), pseudo-steady state effluent concentrations generally ranged from $30-35 \mathrm{mg} \mathrm{RDX} \mathrm{L}{ }^{-1}$ and $2-2.2 \mathrm{mg} \mathrm{HMX} \mathrm{L}^{-1}$. These effluent concentrations were comparable to those observed during the Comp B intermittent-flow experiment, which again suggests that our estimate of the $\mathrm{C} 4$ specific surface area was too low or that C4 dissolves more readily than Comp B. As with Comp B under intermittent-flow conditions, no significant effects of flow stoppage were observed for the first cycle, but in subsequent cycles the RDX and HMX concentrations increased slightly for $3-12 \mathrm{~h}$ after resuming flow.

In general, effluent concentrations were comparable to those observed during the Comp B intermittent-flow experiment, which again suggests that our estimate of the $\mathrm{C} 4$ specific surface area was too low or that $\mathrm{C} 4$ dissolves more readily than Comp B.

\subsection{Apparent dissolution rates}

For each 24-h flow period during each column test, two normalized apparent dissolution rates were calculated for each component of Comp B and C4 (Tables 1 and 2). Mass leaching rates $\left(\mu \mathrm{g} \mathrm{h}^{-1}\right.$ ) for each component (RDX, HMX, or TNT), which were calculated by numerically integrating the product of the effluent concentration and flow rate, were normalized to component mass or component surface area. The mass-normalized dissolution rate $\left(\mu \mathrm{g} \mathrm{h}^{-1} \mathrm{~g}^{-1}\right)$ was calculated by dividing the mass leaching rate by the initial component mass. An apparent 


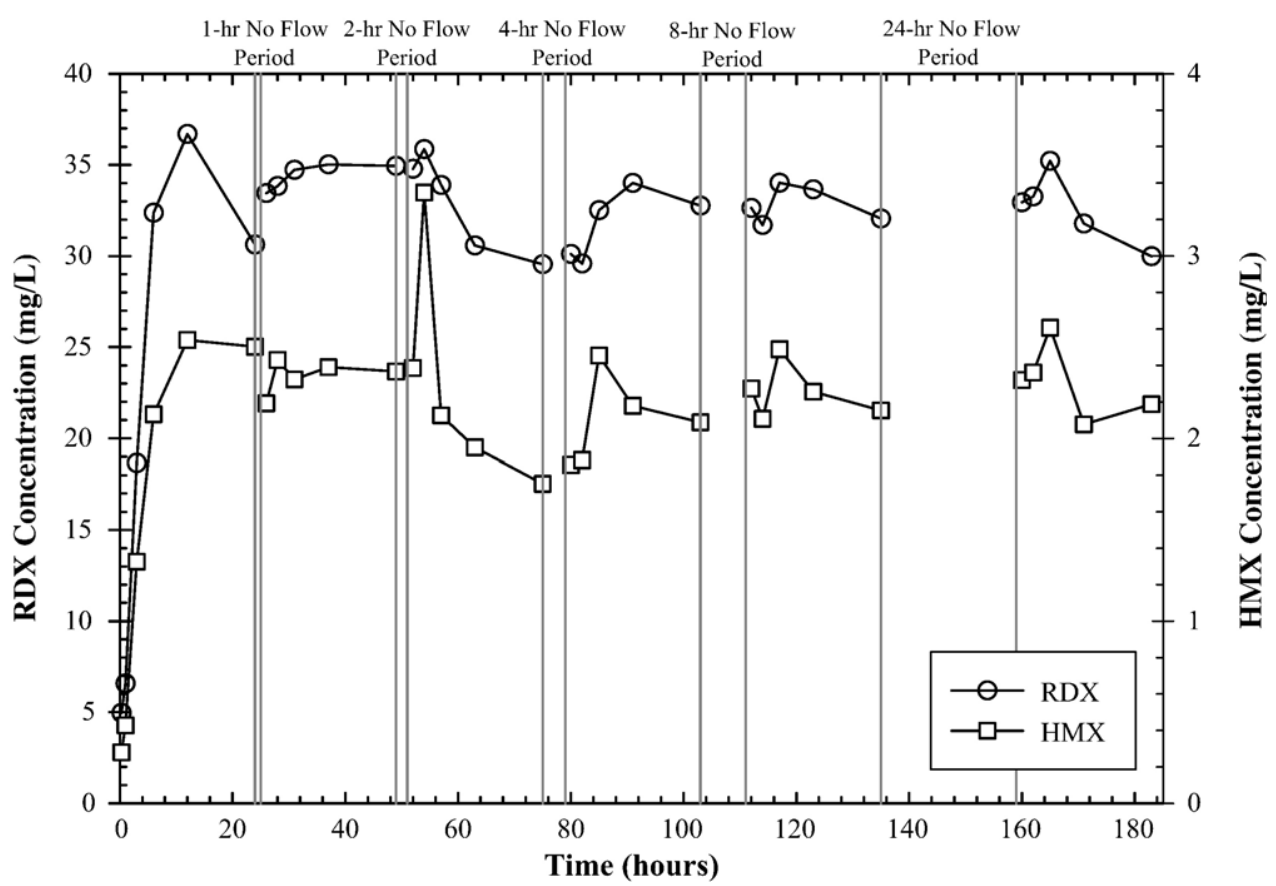

Fig. 4. Effluent RDX and HMX concentrations during the $\mathrm{C} 4$ intermittent flow experiment.

dissolution flux $\left(\mu \mathrm{g} \mathrm{h}^{-1} \mathrm{~cm}^{-2}\right)$ was calculated by dividing the mass-normalized dissolution rate by the estimated component specific surface area (product of $a$ and $\phi$ ). These rates are apparent dissolution rates because they do not fully account for any interactions between HEs and soil (i.e., sorption or transformations) or the expected surface area reductions as HE particles dissolve. Exact dissolution rates would account for these factors and would be somewhat higher than the apparent rates presented in Tables 1 and 2.

For continuous-flow conditions, dissolution rates and fluxes always increased with increasing superficial velocity (Tables 1 and 2), but not in direct proportion to velocity increases (Fig. 5), demonstrating that Comp B and $\mathrm{C} 4$ dissolution is mass transfer limited under these flow conditions. For Comp B, additional flux increases for RDX, HMX, and TNT were not significant after increasing the superficial velocity from 30 to $50 \mathrm{~cm}_{\text {day }}{ }^{-1}$, suggesting that the liquid film mass transfer resistance is minimized at these high flow rates. Dissolution fluxes from $\mathrm{C} 4$ were not maximized, and higher flow rates would likely have produced higher dissolution fluxes of RDX and HMX from C4. Such high superficial velocities $\left(10-50 \mathrm{~cm}^{-1 a y}{ }^{-1}\right)$ are not likely under field conditions, but extrapolation of the dissolution flux data to lower flow rates (Fig. 5) gives some insight into possible dissolution fluxes under saturated flow conditions. Because dissolution rates are strongly dependent on the flow rate (i.e., fluxes decrease with flow rate), these results suggest that dissolution fluxes may be quite small at realistic unsaturated zone flow rates. At the same time, pore water concentrations may approach solubility limits at lower superficial velocities and following periods of no flow (Figs. 1-4).

When normalized to component surface area, the dissolution rates for all three chemicals from Comp B averaged from 9.8 to $13.7 \mu \mathrm{g} \mathrm{h}^{-1} \mathrm{~cm}^{-2}$ under continuous-flow conditions at $10 \mathrm{~cm} \mathrm{day}^{-1}$. At higher flow rates, however, TNT consistently had the highest dissolution flux, 
Table 1

Apparent RDX, HMX, and TNT dissolution rates and fluxes in Comp B column experiments

\begin{tabular}{|c|c|c|c|c|c|c|c|}
\hline \multirow{2}{*}{\multicolumn{2}{|c|}{$\begin{array}{l}\text { Experimental } \\
\text { conditions }\end{array}$}} & \multicolumn{2}{|l|}{ RDX } & \multicolumn{2}{|l|}{ HMX } & \multicolumn{2}{|l|}{ TNT } \\
\hline & & $\begin{array}{l}\text { Mass per } \\
\text { time per } \\
\text { unit mass } \\
\left(\mu \mathrm{g} \mathrm{h}^{-1} \mathrm{~g}^{-1}\right)\end{array}$ & $\begin{array}{l}\text { Mass per } \\
\text { time per unit } \\
\text { surface area } \\
\left(\mu \mathrm{g} \mathrm{h}^{-1} \mathrm{~cm}^{-2}\right)\end{array}$ & $\begin{array}{l}\text { Mass per time } \\
\text { per unit mass } \\
\left(\mu \mathrm{g} \mathrm{h}^{-1} \mathrm{~g}^{-1}\right)\end{array}$ & $\begin{array}{l}\text { Mass per } \\
\text { time per unit } \\
\text { surface area } \\
\left(\mu \mathrm{g} \mathrm{h}^{-1} \mathrm{~cm}^{-2}\right)\end{array}$ & $\begin{array}{l}\text { Mass per time } \\
\text { per unit mass } \\
\left(\mu \mathrm{g} \mathrm{h}^{-1} \mathrm{~g}^{-1}\right)\end{array}$ & $\begin{array}{l}\text { Mass per } \\
\text { time per unit } \\
\text { surface area } \\
\left(\mu \mathrm{g} \mathrm{h}^{-1} \mathrm{~cm}^{-2}\right)\end{array}$ \\
\hline \multicolumn{8}{|c|}{ Continuous flow conditions } \\
\hline $0-24 \mathrm{~h}$ & $10 \mathrm{~cm} \mathrm{~d}^{-1}$ & 903 & 13.7 & 725 & 11.0 & 466 & 7.1 \\
\hline $24-48 \mathrm{~h}$ & $10 \mathrm{~cm} \mathrm{~d}^{-1}$ & 862 & 13.1 & 593 & 9.0 & 851 & 12.9 \\
\hline $48-72 \mathrm{~h}$ & $10 \mathrm{~cm} \mathrm{~d}^{-1}$ & 891 & 13.5 & 620 & 9.4 & 902 & 13.7 \\
\hline $72-96 \mathrm{~h}$ & $30 \mathrm{~cm} \mathrm{~d}^{-1}$ & 2140 & 32.5 & 1200 & 18.1 & 3050 & 46.3 \\
\hline $96-120 \mathrm{~h}$ & $50 \mathrm{~cm} \mathrm{~d}^{-1}$ & 2280 & 34.6 & 1220 & 18.6 & 3200 & 48.5 \\
\hline \multicolumn{8}{|c|}{ Intermittent Flow Conditions $\left(10 \mathrm{~cm} \mathrm{~d}^{-1}\right)$} \\
\hline $0-24 \mathrm{~h}$ & $\begin{array}{l}\text { 1-h No } \\
\text { Flow Period }\end{array}$ & 907 & 13.7 & 671 & 10.2 & 1970 & 29.9 \\
\hline $25-49 \mathrm{~h}$ & $\begin{array}{l}\text { 2-h No } \\
\text { Flow Period }\end{array}$ & 851 & 23.9 & 549 & 8.32 & 1970 & 29.9 \\
\hline $51-75 \mathrm{~h}$ & $\begin{array}{l}\text { 4-h No } \\
\text { Flow Period }\end{array}$ & 787 & 22.1 & 490 & 7.42 & 1750 & 26.6 \\
\hline $79-103 \mathrm{~h}$ & $\begin{array}{l}\text { 8-h No } \\
\text { Flow Period }\end{array}$ & 742 & 20.8 & 488 & 7.39 & 1530 & 23.2 \\
\hline $111-135 \mathrm{~h}$ & $\begin{array}{l}\text { 24-h No } \\
\text { Flow Period }\end{array}$ & 830 & 23.3 & 580 & 8.79 & 1740 & 26.4 \\
\hline $159-183 \mathrm{~h}$ & & 880 & 24.7 & 611 & 9.26 & 1790 & 27.1 \\
\hline Average ( $n$ & =6) & 833 & 21.4 & 565 & 8.56 & 1790 & 27.2 \\
\hline $\begin{array}{l}\text { Standard d } \\
\quad(n-1)\end{array}$ & viation & 60.7 & 4.0 & 71.3 & 1.08 & 165 & 2.5 \\
\hline
\end{tabular}

while HMX consistently had the lowest. Intermittent-flow dissolution of RDX from Comp B initially had the same dissolution flux as for continuous flow $\left(13.7 \mu \mathrm{g} \mathrm{h}^{-1} \mathrm{~cm}^{-2}\right)$, but RDX fluxes increased during later flow periods even though the flow rate remained constant $(\bar{x}=$ $23.0 \mu \mathrm{g} \mathrm{h}^{-1} \mathrm{~cm}^{-2}, n=5 ; s_{n-1}=1.5$ ). HMX was largely unaffected by intermittent flow conditions in our experiments, possibly because it is a minor component of Comp B and therefore has low surface area for dissolution.

Of the three Comp B components, TNT was most drastically affected by intermittent flow conditions. At a superficial velocity of $10 \mathrm{~cm}^{-1 a y}{ }^{-1}$, TNT dissolution rates averaged $740 \mu \mathrm{g} \mathrm{h}^{-1}$ $\mathrm{g}^{-1}\left(n=3 ; s_{n-1}=283\right)$ under continuous-flow, but averaged $1790 \mu \mathrm{g} \mathrm{h}^{-1} \mathrm{~g}^{-1}\left(n=6 ; s_{n-1}=165\right)$ under intermittent flow. These significantly higher dissolution rates resulted in effluent TNT concentrations that peaked after flow was resumed (Fig. 2) to twice the TNT concentrations of the continuous-flow experiments. Higher TNT dissolution rates also resulted in more TNT being leached from the intermittent-flow column $(51.6 \mathrm{mg}$ TNT in $1.21 \mathrm{~L})$ than the continuous-flow column (40.7 mg TNT in $2.22 \mathrm{~L}$ ). These results indicate that TNT readily dissolves from Comp B, even under no-flow conditions. TNT has been found to have the highest rate of dissolution of the three compounds considered in this study (Lynch et al., 2002a) and to dissolve faster than RDX from Comp B (Phelan et al., 2002). 
Table 2

Apparent RDX and HMX dissolution rates and fluxes in C4 column experiments

\begin{tabular}{|c|c|c|c|c|c|}
\hline \multirow{2}{*}{$\begin{array}{l}\text { Experimental } \\
\text { conditions }\end{array}$} & & \multicolumn{2}{|l|}{ RDX } & \multicolumn{2}{|l|}{ HMX } \\
\hline & & $\begin{array}{l}\text { Mass per time } \\
\text { per unit mass } \\
\left(\mu \mathrm{g} \mathrm{h}^{-1} \mathrm{~g}^{-1}\right)\end{array}$ & $\begin{array}{l}\text { Mass per time } \\
\text { per unit surface } \\
\text { area }\left(\mu \mathrm{g} \mathrm{h}^{-1} \mathrm{~cm}^{-2}\right)\end{array}$ & $\begin{array}{l}\text { Mass per time } \\
\text { per unit mass } \\
\left(\mu \mathrm{g} \mathrm{h}^{-1} \mathrm{~g}^{-1}\right)\end{array}$ & $\begin{array}{l}\text { Mass per time } \\
\text { per unit surface } \\
\text { area }\left(\mu \mathrm{g} \mathrm{h}^{-1} \mathrm{~cm}^{-2}\right)\end{array}$ \\
\hline \multicolumn{6}{|c|}{ Continuous flow conditions } \\
\hline $0-24 \mathrm{~h}$ & $10 \mathrm{~cm} \mathrm{~d}^{-1}$ & 560 & 29.8 & 320 & 17.0 \\
\hline $24-48 \mathrm{~h}$ & $10 \mathrm{~cm} \mathrm{~d}^{-1}$ & 459 & 24.4 & 349 & 18.6 \\
\hline $48-72 \mathrm{~h}$ & $10 \mathrm{~cm} \mathrm{day}^{-1}$ & 528 & 28.1 & 326 & 17.4 \\
\hline $72-96 \mathrm{~h}$ & $30 \mathrm{~cm} \mathrm{day}^{-1}$ & 1460 & 77.8 & 723 & 38.5 \\
\hline $96-120 \mathrm{~h}$ & $50 \mathrm{~cm} \mathrm{day}^{-1}$ & 1840 & 97.6 & 870 & 46.3 \\
\hline \multicolumn{6}{|c|}{ Intermittent flow conditions $\left(10 \mathrm{~cm}\right.$ day $\left.{ }^{-1}\right)$} \\
\hline \multirow[t]{2}{*}{$0-24 \mathrm{~h}$} & & 613 & 32.6 & 396 & 21.1 \\
\hline & $\begin{array}{l}\text { 1-h No } \\
\text { Flow Period }\end{array}$ & & & & \\
\hline \multirow[t]{2}{*}{$25-49 \mathrm{~h}$} & & 712 & 46.2 & 436 & 23.2 \\
\hline & $\begin{array}{l}\text { 2-h No } \\
\text { Flow Period }\end{array}$ & & & & \\
\hline \multirow[t]{3}{*}{$51-75 \mathrm{~h}$} & & 653 & 42.4 & 391 & 20.8 \\
\hline & 4-h No & & & & \\
\hline & Flow Period & & & & \\
\hline \multirow[t]{3}{*}{$79-103 \mathrm{~h}$} & & 669 & 43.5 & 397 & 21.1 \\
\hline & 8-h No & & & & \\
\hline & Flow Period & & & & \\
\hline \multirow[t]{3}{*}{$111-135 \mathrm{~h}$} & & 678 & 44.0 & 417 & 22.2 \\
\hline & 24-h No & & & & \\
\hline & Flow Period & & & & \\
\hline \multicolumn{2}{|l|}{$159-183 \mathrm{~h}$} & 661 & 42.9 & 416 & 22.1 \\
\hline \multicolumn{2}{|c|}{ Average $(n=6)$} & 664 & 41.9 & 409 & 21.7 \\
\hline \multicolumn{2}{|c|}{ Standard Deviation $(n-1)$} & 32.2 & 4.8 & 17.2 & 0.91 \\
\hline
\end{tabular}

With the exception of the initial 24-h flow period, apparent dissolution rates of RDX and HMX remained relatively constant during the intermittent flow C4 experiment (Table 2). Dissolution rates and fluxes of RDX and HMX were slightly higher during intermittent flow than those observed during dissolution of $\mathrm{C} 4$ under comparable continuous flow conditions. Higher dissolution rates during intermittent flow shows that RDX and HMX continued to dissolve from $\mathrm{C} 4$ during no-flow periods, yielding higher apparent dissolution rates and some concentration peaks soon after flow was re-started (Fig. 4).

From a practical viewpoint, these results show that the dissolution rates of components from Comp B and C4 particles depend quite considerably on the flow rate and flow cycling through saturated soil. In general, the component dissolution rates decrease as the flow rate decreases, and intermittent flow tends to increase the apparent dissolution rates because of continued dissolution during periods of no flow. In particular, TNT dissolution from Comp B was significantly enhanced during no-flow periods. Although effluent RDX and HMX concentrations were similar, dissolution fluxes were generally higher from $\mathrm{C} 4$ than from Comp B under similar flow conditions, whereas dissolution rates from $\mathrm{C} 4$ normalized to component mass were lower than for Comp B. The differences between dissolution of C4 and Comp B particles can be attributed to variations in the particle sizes, composition, and environmental exposure of the materials used in these experiments. $\mathrm{C} 4$ consisted of weathered particles that were subjected to 


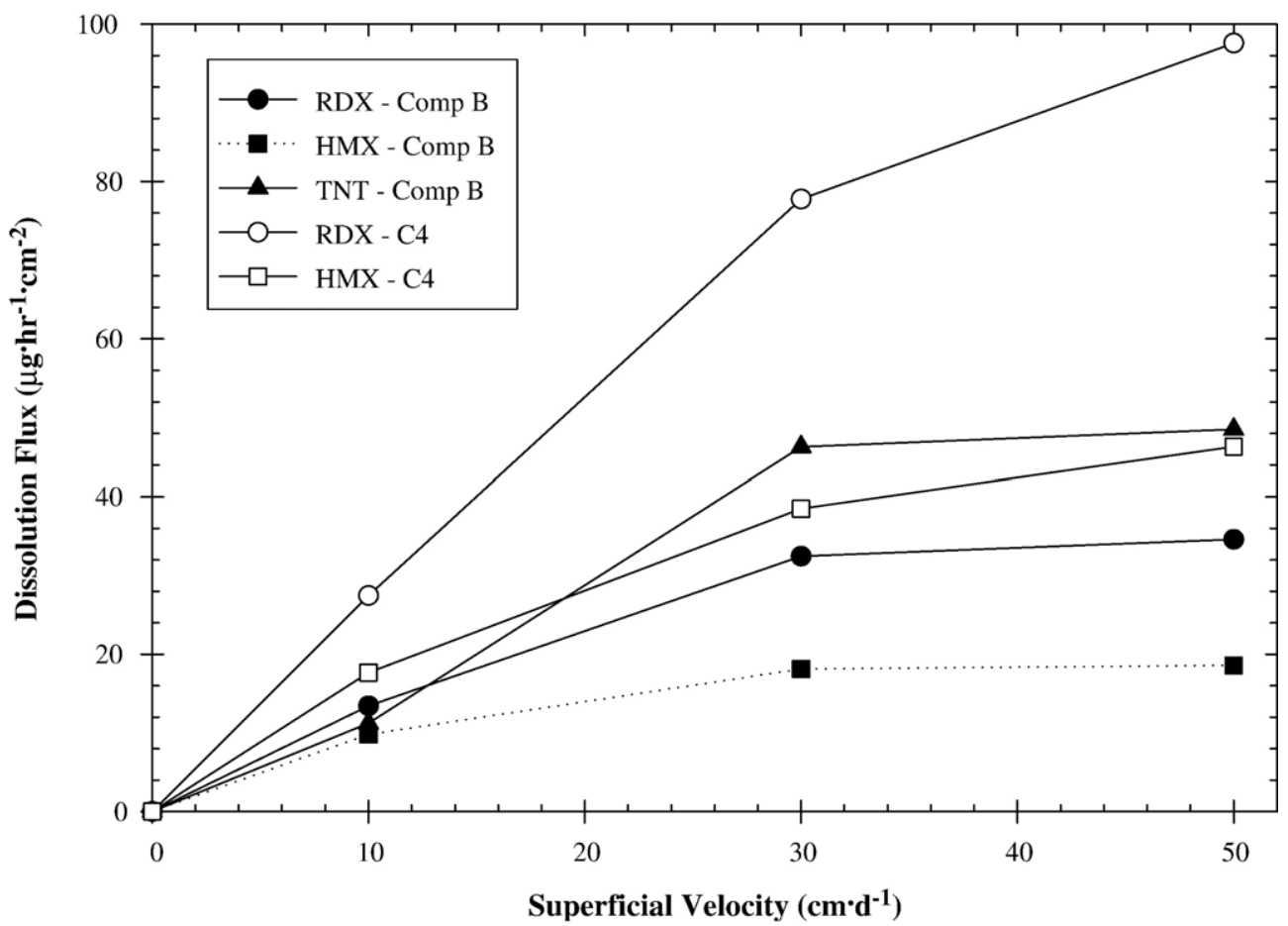

Fig. 5. Apparent dissolution rates $\left(\mu \mathrm{g} \mathrm{h}^{-1} \mathrm{~cm}^{-2}\right)$ as a function of superficial velocity under saturated flow conditions. Surface area for normalization is the fractional surface area of each component.

mechanical size reduction. The resulting $\mathrm{C} 4$ particles were not as well-characterized as the Comp B particles, which were originally extracted from a military munition (Phelan et al., 2003).

While these results shed some light on potential dissolution rates of HE components from $\mathrm{C} 4$ and Comp B, the water content of near-surface soils under field conditions is expected to be substantially less than that in these saturated soil column experiments. Therefore, the dissolution rates that may occur in unsaturated soils under field conditions are likely to be substantially lower than those observed in our soil column experiments because of low infiltration rates. This may also result in pore water concentrations approaching solubility limits because contaminant concentrations increase with decreasing flow rates.

The results presented in Tables 1 and 2 could be used to estimate the time required for dissolution of HE particles. For example, the dissolution rate of RDX from Comp B was about $885 \mu \mathrm{g} \mathrm{h}^{-1} \mathrm{~g}^{-1}$ at a continuous flow rate of $10 \mathrm{~cm} \mathrm{day}^{-1}$, and the TNT dissolution rate under the same conditions approached a similar value. Thus, TNT may disappear first from Comp B because it is present at a lower mass fraction. Field evidence suggests that extending these simplified calculations to complete particle disappearance using these normalized rates is flawed because HE particles are persistent in near surface training range soils. At the eastern US military installation, Comp B particles were found as recently as 2004 in surface soil samples from areas that have not received HE ordnance discharge since 1997 (Pennington et al., 2005). In reality, there are many interrelated variables that affect the dissolution rate, including degree of weathering of the explosive, HE particle size distributions, moisture content, and flow rate through the soil (Brannon et al., 1999). Because of the complexity of variables, additional long-term experiments 
Table 3

Comparison of reported dissolution fluxes of RDX, HMX, and TNT in completely stirred aqueous systems to saturated soil columns (this work)

\begin{tabular}{llrlll}
\hline \multicolumn{2}{l}{ Dissolution } & Flux $\left(\mu \mathrm{g} \mathrm{h}^{-1} \mathrm{~cm}^{-2}\right)$ & & Experimental conditions & Source \\
\cline { 1 - 2 } RDX & HMX & TNT & & & \\
\hline 360 & 702 & 4164 & & Pure High Explosives & Brannon et al. (1999) \\
180 & 780 & 840 & & Pure High Explosives, $20{ }^{\circ} \mathrm{C}, 150 \mathrm{rpm}$ & Lynch et al. (2002a) \\
193 & 522 & 840 & & Pure High Explosives, $20{ }^{\circ} \mathrm{C}, 150 \mathrm{rpm}$ & Lynch et al. (2002b) \\
165 & 268 & 1044 & & Comp B, $20{ }^{\circ} \mathrm{C}, 150 \mathrm{rpm}$ & Lynch et al. (2002b) \\
3600 & NA & 11,400 & & Comp B, $22-23{ }^{\circ} \mathrm{C}, 225 \mathrm{rpm}$ & Phelan et al. (2002) \\
13.4 & 9.8 & 11.2 & & Comp B; packed bed; $10 \mathrm{~cm} \cdot \mathrm{day}^{-1}$ & This research; continuous flow \\
21.4 & 8.6 & $27.2^{\mathrm{a}}$ & & Comp B; packed bed; $10 \mathrm{~cm} \cdot \mathrm{day}^{-1}$ & This research; intermittent flow \\
27.4 & 17.7 & - & & C4; packed bed; $10 \mathrm{~cm} \cdot \mathrm{d}^{-1}$ & This research; continuous flow \\
$41.9^{\mathrm{b}}$ & $21.7^{\mathrm{c}}$ & - & & C4; packed bed; $10 \mathrm{~cm} \cdot \mathrm{d}^{-1}$ & This research; intermittent flow \\
\hline
\end{tabular}

$\mathrm{NA}=$ not available.

Maximum dissolution fluxes:

Fluxes reported per $\mathrm{cm}^{2}$ of the chemical of interest. The assumed Comp B composition was 54\% RDX, 6\% HMX, and $40 \%$ TNT, and the assumed C4 composition was $81.9 \%$ RDX and 9.1\% HMX.

${ }^{\mathrm{a}} \mathrm{TNT}: \bar{x}=27.2 \mu \mathrm{g} \mathrm{h}^{-1} \mathrm{~cm}^{-2}, \mathrm{n}=6, s_{n-1}=2.5$.

${ }^{\mathrm{b}} \mathrm{RDX}: \bar{x}=41.9 \mu \mathrm{g} \mathrm{h}^{-1} \mathrm{~cm}^{-2}, \mathrm{n}=6, s_{n-1}=4.8$.

${ }^{\mathrm{c}}$ HMX: $\bar{x}=21.7 \mu \mathrm{g} \mathrm{h}^{-1} \mathrm{~cm}^{-2}, \mathrm{n}=6, s_{n-1}=0.91$.

exploring a wider range of potential environmental conditions may be useful for more accurately estimating HE particle dissolution rates.

Previously reported RDX, HMX, and TNT dissolution fluxes from pure high explosives (Brannon et al., 1999; Lynch et al., 2002a,b) and from Comp B (Phelan et al., 2002) are significantly higher than the maximum values observed in our column tests, which occurred under intermittent flow conditions (Table 3). Contaminant dissolution fluxes from $\mathrm{C} 4$ have not been previously reported. Our results demonstrate dramatically lower fluxes from HE particles in saturated soil columns as compared to well-mixed batch reactors with no soil, presumably because of a higher degree of mixing intensity associated with the latter. A higher degree of mixing is likely to increase mass transfer coefficients or cause HE particles to disintegrate, thereby increasing the HE particle surface area and the dissolution rate. Our experimental results also suggest that dissolution of HE particles may be very slow under field conditions and that HE particles are likely to be a persistent source of leachable contaminants.

\subsection{Dissolution modeling}

The steady state models presented earlier were used to estimate mass transfer coefficients for dissolution of each component during continuous flow experiments. Results of steady-state column modeling are summarized in Table 4, which includes the average steady state effluent concentrations used in the model, the standard deviation of each average concentration, and the number of data points used to estimate the mass transfer coefficient $\left(k_{\mathrm{f}}\right)$, as well as the resulting best-fit $k_{\mathrm{f}}$ values for the steady state model that includes dispersion (Eqs. (6) and (7)). In general, the model that included dispersion provided good fits of steady state concentrations in all continuous-flow experiments. For all conditions analyzed, the resulting $k_{\mathrm{f}}$ values increased with superficial velocity; however, $k_{\mathrm{f}}$ increases were nonlinear. In all cases, the increase in $k_{\mathrm{f}}$ was not very significant when superficial velocity was increased from $30 \mathrm{~cm}$ day $^{-1}$ to $50 \mathrm{~cm}$ day $^{-1}$, suggesting that $k_{\mathrm{f}}$ reached a maximum at these high superficial velocities. 
Table 4

Summary of steady-state modeling results for Comp B and C4

\begin{tabular}{|c|c|c|c|c|}
\hline \multirow[t]{2}{*}{ Chemical } & \multirow[t]{2}{*}{ Parameter } & \multicolumn{3}{|c|}{ Approach velocity $\left(\mathrm{cm} \cdot \mathrm{day}^{-1}\right)$} \\
\hline & & 10 & 30 & 50 \\
\hline \multirow[t]{4}{*}{ RDX (Comp B) } & Avg. $\mathrm{C}\left(\mathrm{mg} \cdot \mathrm{L}^{-1}\right)$ & 28.1 & 19.6 & 14.5 \\
\hline & Std. Dev. & 0.67 & 0.54 & 0.081 \\
\hline & $n$ & 6 & 3 & 4 \\
\hline & $k_{\mathrm{f}}\left(\mathrm{cm} \mathrm{day}{ }^{-1}\right)$ & 14.4 & 22.7 & 24.6 \\
\hline \multirow[t]{4}{*}{ HMX (Comp B) } & Avg. C (mg L $\left.{ }^{-1}\right)$ & 1.89 & 1.27 & 0.87 \\
\hline & Std. Dev. & 0.071 & 0.012 & 0.034 \\
\hline & $n$ & 6 & 3 & 5 \\
\hline & $k_{\mathrm{f}}\left(\mathrm{cm} \mathrm{day}^{-1}\right)$ & 82.8 & 137.2 & 141 \\
\hline \multirow[t]{4}{*}{ TNT (Comp B) } & Avg. C (mg L $\left.{ }^{-1}\right)$ & 21.3 & * & 15.2 \\
\hline & Std. Dev. & 0.25 & $*$ & 0.57 \\
\hline & $n$ & 2 & $*$ & 4 \\
\hline & $k_{\mathrm{f}}\left(\mathrm{cm} \mathrm{day}{ }^{-1}\right)$ & 3.38 & * & 11.4 \\
\hline \multirow[t]{4}{*}{ RDX (C4) } & Avg. C (mg L $\left.{ }^{-1}\right)$ & 30.5 & 23.5 & 17.7 \\
\hline & Std. Dev. & 0.75 & 0.98 & 0.77 \\
\hline & $n$ & 5 & 4 & 4 \\
\hline & $k_{\mathrm{f}}\left(\mathrm{cm} \mathrm{day}{ }^{-1}\right)$ & 39.6 & 71.1 & 75.6 \\
\hline \multirow[t]{4}{*}{ HMX (C4) } & Avg. C (mg L $\left.{ }^{-1}\right)$ & 1.88 & 1.29 & 0.93 \\
\hline & Std. Dev. & 0.076 & 0.067 & 0.030 \\
\hline & $n$ & 4 & 4 & 4 \\
\hline & $k_{\mathrm{f}}\left(\mathrm{cm}\right.$ day $\left.^{-1}\right)$ & 190 & 324 & 353 \\
\hline
\end{tabular}

Avg. $\mathrm{C}=$ average steady-state effluent concentration used to determine $k_{\mathrm{f}}$.

Std. Dev. $=$ standard deviation $(n-1)$ in the average concentration. $n=$ number of concentration measurements in determining Avg. C.

* = effluent TNT concentration did not reach steady state.

For Comp B and C4, mass transfer coefficients for HMX were considerably than those of RDX at each flow rate, possibly due to it small fractional surface area. The available values for TNT suggest that it had the lowest $k_{\mathrm{f}}$ at each superficial velocity in the Comp B experiments. Higher $k_{\mathrm{f}}$ values for dissolution of $\mathrm{C} 4$ indicate that $\mathrm{C} 4$ dissolves more readily than Comp $\mathrm{B}$, as also suggested by flux data presented earlier.

To generalize the derived mass transfer coefficients, Sherwood numbers $(S h)$ for each component were calculated using Eqs. (10) and (11) and are presented as a function of Re in Fig. 6, which also includes predicted $S h$ values based on the Powers et al. (1994) correlation. For RDX and TNT dissolution from Comp B, there is very good agreement with the Powers correlation. HMX results from Comp $\mathrm{B}$ and $\mathrm{C} 4$, as well as $\mathrm{RDX}$ results from $\mathrm{C} 4$, are underestimated by the Powers correlation. The higher estimated values for components from $\mathrm{C} 4$ may be a function of the uncertainty in the assumed specific surface area of our $\mathrm{C} 4$ particles. The model is fairly sensitive to the specific surface area; doubling the HE particle specific surface area halves the resulting Sherwood number. Thus, if our C4 particles were actually smaller than the assumed 2-mm diameter, the Sherwood numbers would agree more closely. The good agreement between the published correlation and our Comp B results for RDX and TNT suggest that the Powers correlation is a satisfactory starting point for estimating dissolution rates of $\mathrm{HE}$ particles in saturated-flow soil columns. Furthermore, if the soil porosity, bulk density, and median soil particle diameter are known, the steady state dissolution model can be used to estimate pore water concentrations in other soil types under various flow conditions.

If dispersion were neglected (Eq. (8)), the optimal $k_{\mathrm{f}}$ and resulting $S h$ for each condition would be somewhat lower. For example, when accounting for dispersion, $k_{\mathrm{f}}=39.6 \mathrm{~cm}$ day $^{-1}$ and 


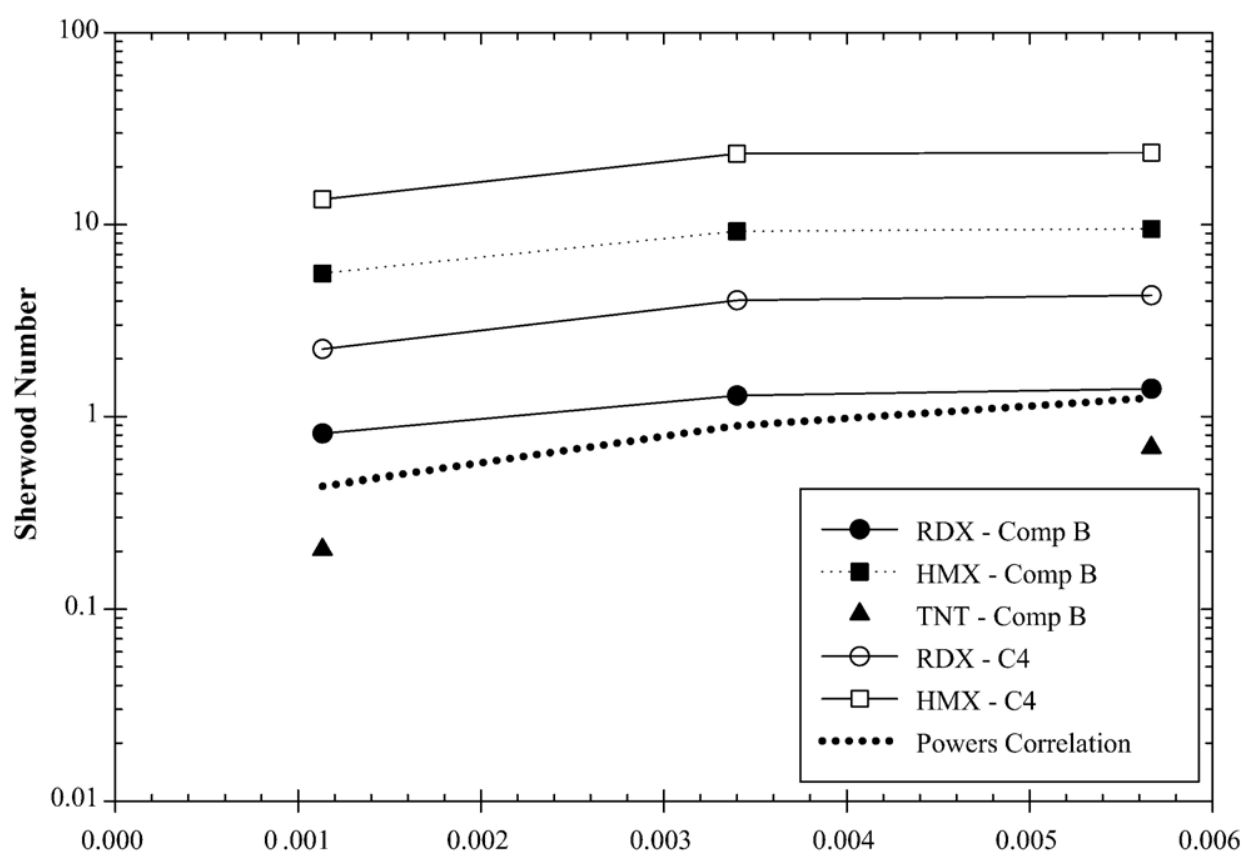

Reynolds Number

Fig. 6. Correlation of Sherwood number to Reynolds number in continuous flow experiments.

$S h=2.24$ for RDX dissolving from C4 at a superficial velocity of $10 \mathrm{~cm}^{-1 a y}{ }^{-1}$ (Table 4; Fig. 6), whereas $k_{\mathrm{f}}=28.5 \mathrm{~cm} \mathrm{day}^{-1}$ and $S h=1.62$ when dispersion is neglected (data not shown). The differences in $k_{\mathrm{f}}$ values tend to decrease with increasing flow velocity, as the effects of dispersion diminish at higher flow rates. Under field conditions with relatively low flow velocities, dispersion is likely to be an important mass transport mechanism and thus should not be neglected.

Although the steady state model with dispersion yielded good model fits and reasonably good agreement with the Powers et al. (1994) correlation, the major assumptions of the steady-state dissolution model must be critiqued. The major assumption in developing the model was that the specific surface area and mass of source HE particles do not vary over time, which eliminated the need for an explicit mass balance in the model formulation. This assumption is clearly unrealistic, particularly during field-scale dissolution of HE particles over long time periods. Our experiments, however, were not conducted for sufficient duration to observe substantial HE source depletion During the continuous-flow Comp B experiment, approximately $17 \%, 11 \%$, and $20 \%$ of the initial RDX, HMX, and TNT exited the column, while $9.2 \%$ and $6.2 \%$ of the initial RDX and HMX leached from the continuous flow $\mathrm{C} 4$ column. These mass decreases were not sufficient to cause sustained decreases in effluent HE concentrations; however, corresponding decreases in component surface areas create a small degree of uncertainty in the model results (Table 4; Fig. 6) and the apparent dissolution fluxes (Tables 1 and 2), particularly near the end of each experiment. For the steady state model with dispersion, decreasing the particle diameter by $50 \%$ doubles the HE particle specific surface area and decreases $S h$ by $50 \%$, demonstrating the importance of careful contaminant source characterization. Longer duration experiments would certainly be useful for observing concentration and flux responses as the HE source is depleted, and could more accurately represent the non-steady state conditions expected in real systems. 


\section{Conclusions}

Saturated soil column experiments showed that Comp B and C4 particles readily dissolved at high superficial velocities. In general, higher flow rates yielded higher dissolution rates and higher mass transfer coefficients for all components. Although lower flow rates resulted in higher effluent concentrations, solubility limits were not achieved. Dissolution rates were significantly lower than previously reported dissolution rates, indicating that dissolution in saturated soil columns is much slower than in well-mixed batch reactors. Cycling between flow and no-flow conditions had a small effect on the dissolution rates and effluent concentrations; however, TNT dissolution from Comp B was significantly enhanced under intermittent-flow conditions. In Comp B column experiments, TNT dissolution rates were generally higher than those of RDX and HMX. Our results indicate that solid HE particles will be a significant source of dissolved HEs in pore water over long periods of time. These experimental results and the corresponding steady-state model yield important new information about dissolution of HE particles. In particular, the steady-state model provides a starting point for estimating HE mass transfer from Comp B and C4 particles and the resulting pore water concentrations under different flow conditions in saturated soils.

\section{Acknowledgements}

This work was funded by AMEC Earth and Environmental, Inc. under contract to the National Guard Bureau. We also thank Dr. Robin Autenrieth and Dr. Thomas McDonald at Texas A\&M University for performing the high explosives analyses.

\section{References}

Brannon, J.M., Deliman, P., Ruiz, C., Price, C., Qasim, M., Gerald, J.A., Hayes, C.A., Yost, S., 1999. Conceptual Model and Process Descriptor Formulations for Fate and Transport of UXO. Technical Report IRRP-99-1. U.S. Army Corps of Engineers, Waterways Experiment Station, Vicksburg, MS.

Clausen, J.L., Robb, J., Curry, D., Korte, N., 2004. A case study of contaminants on military ranges: Camp Edwards, Massachusetts, USA. Environ. Pollut. 129, 13-21.

Fedoroff, B.T., Sheffield, O.E., 1966. Encyclopedia of Explosives and Related Items, Picatinny Arsenal Technical Report 2700, vol. 3. Picatinny Arsenal, Dover, NJ.

Freeze, R.A., Cherry, J.A., 1979. Groundwater. Prentice-Hall, Englewood Cliffs, NJ.

Jenkins, T.F., Pennington, J.C., Ranney, T.A., Berry Jr., T.E., Miyares, P.H., Walsh, M.E., Hewitt, A.D., Perron, N.M., Parker, L.V., Hayes, C.A., Wahlgren, E.G., 2001. Characterization of Explosives Contamination at Military Firing Ranges. ERDC TR-01-5. U.S. Army Engineer Research and Development Center, Cold Regions Research and Engineering Laboratory, Hanover, NH.

Jenkins, T.F., Walsh, M.E., Miyares, P.H., Hewitt, A.D., Collins, N.H., Ranney, T.A., 2002. Use of snow-covered ranges to estimate explosives residues from high-order detonations of army munitions. Thermochim. Acta 384, $173-185$.

Lynch, J.C., Brannon, J.M., Delfino, J.J., 2002a. Dissolution rates of three high explosive compounds: TNT, RDX, and HMX. Chemosphere 47, 725-734.

Lynch, J.C., Brannon, J.M., Delfino, J.J., 2002b. Effects of component interactions on the aqueous solubilities and dissolution rates of the explosive formulations octol, composition B, and LX-14. J. Chem. Eng. Data 47, 542-549.

Monteil-Rivera, F., Paquet, L., Deschamps, S., Balakrishnan, V.K., Beaulieu, C., Hawari, J., 2004. Physico-chemical measurements of CL-20 for environmental applications Comparison with RDX and HMX. J. Chromatogr., A 1025, $125-132$.

Pennington, J.C., Jenkins, T.F., Ampleman, G., Thiboutot, S., Brannon, J.M., Lynch, J., Ranney, T.A., Stark, J.A., Walsh, M.E., Lewis, J., Hayes, C.A., Mirecki, J.E., Hewitt, A.D., Perron, N., Lambert, D., Clausen, J., Delfino, J.J., 2002. Distribution and Fate of Energetics on DoD Test and Training Ranges: Interim Report 2. Technical Report TR-02-8. 
U.S. Army Corps of Engineers, Engineering Research and Development Center. Waterways Experiment Station, Vicksburg, MS.

Pennington, J.C., Jenkins, T.F., Thiboutot, S., Ampleman, G., Clausen, J., Hewitt, A.D., Lewis, J., Walsh, M.R., Walsh, M.E., Ranney, T.A., Silverblatt, B., Marois, A., Gagnon, A., Brousseau, P., Zufelt, J.E., Poe, K., Bouchard, M., Martel, R., Walker, D.D., Ramsey, C.A., Hayes, C.A., Yost, S.L., Bjella, K.L., Trepanier, L., Berry, T.E., Lambert, D.J., Dubé, P., Perron, N.M., 2005. Distribution and Fate of Energetics on DoD Test and Training Ranges: Interim Report 5. ERDC TR-05-2. US Army Corps of Engineers, Environmental Research and Development Center. Prepared for Strategic Environmental Research and Development Program. Vicksburg, MS.

Phelan, J.M., Romero, J.V., Barnett, J.L., Parker, D.R., 2002. Solubility and Dissolution Kinetics of Composition B Explosive in Water. Sand Report SAND2002-2420. Sandia National Laboratories, Albuquerque, NM.

Phelan, J.M., Webb, S.W., Romero, J.V., Barnett, J.L., Griffin, F., Eliassi, M.I., 2003. Measurement and Modeling of Energetic Material Mass Transfer to Soil Pore Water - Project CP-1227 Annual Technical Report. SAND2003-0153, Sandia National Laboratories, Albuquerque, NM, January 2003.

Powers, S.E., Abriola, L.M., Dunkin, J.S., Weber Jr., W.J., 1994. Phenomenological models for transient NAPL-water mass-transfer processes. J. Contam. Hydrol. 16, 1-33.

Radtke, C.W., Smith, D.M., Owen, G.S., Roberto, F.F., 2002. Field demonstration of acetone pretreatment and composting of particulate-TNT-contaminated soil. Bioremediat. J. 6 (2), 191-204.

Rosenblatt, D.H., Burrows, E.P., Mitchell, W.R., Parmer, D.L., 1991. Organic explosives and related compounds. In: Hutzinger, O. (Ed.), The Handbook of Environmental Chemistry Volume 3: Anthropogenic Compounds. SpringerVerlag, Berlin, pp. 195-234. Part G.

Taylor, S., Hewitt, A., Lever, J., Hayes, C., Perovich, L., Thorne, P., Daghlian, C., 2004. TNT particle size distributions from detonated 155-mm howitzer rounds. Chemosphere 55, 357-367.

U.S. Environmental Protection Agency (USEPA), 1994. Nitroaromatics and Nitramines by High Performance Liquid Chromatography (HPLC), SW-846, Method 8330. Revision 4, September 1994. Office of Solid Waste and Emergency Response, Washington, DC.

Yamamoto, H., Morley, M.C., Speitel Jr., G.E., Clausen, J.L., 2004. Fate and transport of high explosives in a sandy soil: adsorption and desorption. Soil Sediment Contam.: Int. J. 13 (5), 1-19. 